\title{
The Campaign Dynamics of Economic Voting
}

\author{
J. Scott Matthews (johnmatt@interchange.ubc.ca) \\ University of British Columbia
}

** Draft version. Please do not cite without author's permission. **

Paper prepared for the Canadian Political Science Association Annual Meetings, June 2 to 4, 2005, London, Ontario. The author gratefully acknowledges the support, in the form of a doctoral fellowship, of the Social Sciences and Humanities Research Council of Canada. The author would also like to thank Richard Johnston, Fred Cutler, Paul Quirk, and Amanda Bittner for assistance in the preparation of this paper. None of these parties are responsible for the arguments of, or errors in, this paper. 


\section{The Campaign Dynamics of Economic Voting}

The link between the state of the economy and the vote is ubiquitous, but it is not invariant. We know that the relationship varies across space-across nations and institutional contexts (Powell and Whitten 1993; Anderson 1995; Royed, Leyden and Borelli 2000; Nadeau, Niemi and Yoshinaka 2002; Palmer and Whitten 2003). Does the link also vary over time? In particular, does the relationship between the economy-or, more precisely, perceptions of economic performance-and vote choice change over the course of election campaigns?

Theory suggests diverse possible answers. The most common assumption is that the impact of the economy grows with time in the campaign (Markus 1988, 1992; Bartels 1992, Forthcoming; Finkel 1993; Gelman and King 1993; Campbell 2000, 2001; see also Johnston, Hagen and Jamieson 2004). The claim is intuitively plausible and rests on a simple premise: one candidate or another always has an incentive to emphasize economic considerations in their campaign appeals (Campbell 2001). In good times, governing parties seeking reward have a strong incentive to prime economic considerations. In bad times, opposition parties seeking to effect punishment have an equally strong incentive to draw voter attention to the economy. Thus, to the extent that campaign discourse has a decisive impact on the set of considerations voters emphasize on election day, the typical campaign should witness a (more or less) steady increase in the impact of economic evaluations on vote choice. ${ }^{1}$

But the campaign may also divert voter attention from economic considerations. The literature on cognitive heuristics, at least in its more rationalist formulations, suggests that

\footnotetext{
${ }^{1}$ The only direct evidence supporting the claim is in Bartels (Forthcoming). Pooling survey data from two decades of US presidential elections, he finds that the impact of the economy is typically twice as large at the end of the campaign than at the beginning. A spate of more indirect evidence corroborates this conclusion, most of it also drawing on the US case (Gelman and King 1993; Finkel 1993; Campbell 2000; Bafumi, Gelman and Park 2004). Outside the US the case is less convincing: existing evidence is almost entirely indirect and support for the hypothesis is "modest" at best (Stevenson and Vavreck 2000; Arceneaux 2004; Sekhon 2004; but see Andersen, Tilley and Heath 2005). Even in the US the case for the conventional wisdom is looking shaky, especially in the wake of Election 2000: that year, the economy seemed to be the dog that just wouldn't bark (Johnston, Hagen and Jamieson 2004; see also Campbell 2001; Holbrook 2001; Norpoth 2001).
} 
part of the impulse to rely on economic evaluations, partisanship and the like in political reasoning stems from the desire to economize on cognitive effort (Downs 1957; Popkin 1991; Lupia and McCubbins 1998; see also Fiorina 1981). Absent the informational onslaught of the campaign, perhaps the most ubiquitous source of knowledge about government performance comes from the individual's experience in the real economy. ${ }^{2}$ Insofar as the link between the economy and evaluations of the government is obvious, the typical individual outside of the campaign period may base much of his/her assessment of political incumbents on economic evaluations. The start of the campaign could easily stifle this reasoning process, as non-economic considerations-issues, candidate evaluations, etc.- - suddenly seem more relevant to vote choice, as indeed they may be. Thus, economic effects might decline as the campaign begins, even as they may recover closer to election day.

A third possibility is that the campaign has no regular impact on the economy-vote link. If campaigns really matter - that is, if campaigns sometimes have an impact on election outcomes that cannot be predicted in advance (Johnston et al. 1992; Holbrook 1996; Shaw 1999) - then we have little reason to expect any particular pattern in the campaign dynamics of economic voting to be common across elections.

The key empirical questions are, thus: is there a pattern?; and, if so, what is it? The present paper seeks to answer these questions by drawing on a body of data uniquely suited to analysis of campaign dynamics: the ten rolling cross-section (RCS) election studies conducted in Canada, New Zealand, the United Kingdom and the United States between 1988 and 2003. RCS survey methodology essentially produces a random sample of respondents for each day of the survey period (typically the length of the campaign), permitting analysis of subtle dynamics in voter cognition as the campaign unfolds (Johnston and Brady 2002). Deploying these data thus affords a direct

\footnotetext{
${ }^{2}$ Popkin (1991) makes the strongest argument for this view.
} 
examination of the campaign dynamics of economic voting, one that is comparative and, in the main, unprecedented. ${ }^{3}$

The implications of the analysis are both theoretical and practical. On the theoretical side, the results clearly speak to arguments about 'campaign enlightenment' - in short, the view that the major effect of the campaign is to inform voters about and draw voter attention to a set of 'fundamental variables' (the economy, issues, partisanship) relevant to the vote decision (Gelman and King 1993). The campaign dynamics of economic voting are a crucial test of this hypothesis, insofar as economic evaluations are at least potentially responsive to changes in real world conditions-something that is hard to say for some of the other 'fundamentals,' like partisanship. On the practical side, the analysis is also relevant to election forecasting models - which typically include representations of the economy as crucial terms - and the interpretation of trial heat polls. For the former, the results may help to clarify when the forecasting models are likely to 'work'; for the latter, the analysis speaks to the question of what campaign period polls typically 'mean,' and when they mean it. More on these points below.

The paper is organized as follows. First, a search for regular trends in the dynamics of economic effects on vote choice. This proceeds through estimation of vote equations that model the impact of 'campaign time' on the magnitude of economic effects. Results here lead to a second, more inductive stage in the analysis, which focuses on graphical renderings of day-to-day changes in economic effects across the elections. This 'closer look' at the dynamics gives pause for reconsideration of some of the trends suggested in the first section of the paper and also uncovers something unexpected: an apparent pattern in the dynamics of economic effects not contemplated in the existing literature on campaigns. The paper closes with concluding discussion.

\footnotetext{
${ }^{3}$ Johnston, Hagen and Jamieson (2004) offer the clearest precedent in their treatment of dynamics in the impact of the economy in the 2000 US presidential election campaign. The comparative breadth of the present analysis, however, is unique in the literature employing RCS data.
} 


\title{
Modelling the Campaign Dynamics of Economic Effects
}

\author{
Methodology
}

As noted above, the data for this analysis are RCS survey data collected during ten different elections across four different countries. The election studies are, for Canada, the Canadian Election Studies from 1988 to $2000^{4}$; for Ontario, the Ontario Election Study, 20035; for New Zealand, the New Zealand Election Studies from 1996 to $2002^{6}$; for the United Kingdom, the British Election Study, 2001 ; and for the United States, the National Annenberg Election Study, 2000. ${ }^{8}$ Although each study contains multiple components, only two components of each study are utilized here: the campaign period RCS survey and the post-election survey. ${ }^{9}$

The basic modeling strategy is to regress support for the incumbent party (or presidential candidate of the incumbent party in the US) on economic evaluations (ECONEVAL) and

\footnotetext{
${ }^{4}$ Data from the 1988 Canadian National Election Study, funded by the Social Sciences and Humanities Research Centre (SSHRC), were collected by the Institute for Social Research (ISR), York University for Richard Johnston, André Blais, Henry E. Brady and Jean Crête. Data from the 1993 Canadian Election Study were provided by the ISR. The survey was funded by the SSHRC and was completed for the 1992/93 Canadian Election Team of Richard Johnston, André Blais, Henry Brady, Elisabeth Gidengil and Neil Nevitte. Data for the 1997 Canadian Election Study were provided by the ISR. The survey was funded by the SSHRC and was completed for the 1997 Canadian Election Team of André Blais, Elisabeth Gidengil, Richard Nadeau and Neil Nevitte. Data from the 2000 Canadian Election Study were collected by the ISR and the Jolicoeur \& Associates for André Blais, Elisabeth Gidengil, Richard Nadeau and Neil Nevitte. The survey was funded by the SSHRC, Elections Canada and the Institute for Research on Public Policy. Neither the organizations that collected and distributed the data, the agencies that funded the data collection, nor the election teams that supervised the data collection are responsible for the analyses and interpretations presented here.

${ }^{5}$ Principal investigators Fred Cutler and Greg Lyle, Co-investigators Andre Blais, Patrick Fournier, Stuart Soroka.

${ }^{6}$ For the NZES 1996, the principal investigators were Jack Vowles, Peter Aimer, Helena Catt, Raymond Miller, Susan Banducci, Jeffrey Karp, and David Denemark. For the NZES 1999, the principal investigators were Jack Vowles, Peter Aimer, Raymond Miller, Ann Sullivan, Susan Banducci, and Jeffrey Karp. For the NZES 2002, the principal investigators were Jack Vowles, Peter Aimer, Raymond Miller, Susan Banducci, and Jeffrey Karp.

${ }^{7}$ For the BES 2001, the principal investigators were David Sanders, Paul Whiteley, Harold Clarke and Marianne Stewart.

${ }^{8}$ For the NAES 2000, the principal investigators were Richard Johnston, Kathleen Hall Jamieson and Michael G. Hagen.

${ }^{9}$ As noted above, RCS survey methodology produces a random sample of respondents for each day of the survey period (typically the length of the campaign). The size of the daily sample generally ranges from roughly 100 — as is typical of RCS data collected by the Canadian Election Study - to over 300 - the peak daily sample size in the National Annenberg Election Study in 2000.
} 
interactions of economic evaluations with campaign time (DAY), while controlling for important socio-demographics and party identification. ${ }^{10}$ Two sets of models are examined: one that models the dynamics of economic effects as a linear function of time and one that models the dynamics as a curvilinear function of time. The latter is accomplished by adding an interaction between economic evaluations and the square of $D A Y\left(E C O N E V A L^{*} D A Y^{2}\right)$ to the former model, which includes only an interaction between economic evaluations and DAY (ECONEVAL $\left.{ }^{*} D A Y\right) .{ }^{11}$ Models are estimated by logit, separately for each election. ${ }^{12}$

A note on the measurement of economic evaluations. Economic effects on vote choice have been widely studied, so survey instrumentation concerning economic evaluations is commonplace and reasonably comparable across surveys. In the present sample of elections the typical item is some minor variation on the following:

How do you think the general economic situation in New Zealand now compares with a year ago? Is it the same, better or worse? [NZES 1999]

All but three of the surveys (NAES 2000, NZES 2002, OES 2003) contain an item of this sort and, in the deviant surveys, reasonable proxies are easily found. ${ }^{13}$ Even so, wording

\footnotetext{
${ }^{10}$ Each vote model includes socio-demographic terms derived from the work of the principal investigators of each respective election study. The models include variables for all major party identifications. Details available from the author.

${ }^{11}$ Models include main effects of $D A Y$ and $D A Y^{2}$, as appropriate. That is, only the former in the linear models, and both in the curvilinear ones. Note also that the models are estimated with robust standard errors, correcting for clustering of observations within campaign days. This takes account of the fact that average levels of incumbent support may be higher or lower on certain days, even controlling for the variables included in the models. This results in slightly larger standard errors than would be obtained with the conventional calculation.

${ }^{12}$ Note that estimating separate models for Quebec and the 'Rest of Canada' (ROC), as has become the norm in analysis of Canadian elections (e.g. Blais et al. 2002), does little to disturb the interpretation of the dynamics of economic effects presented here. The general pattern of effects is common across the two sets of estimations, save for a minor deviation in 2000: that year, economic effects in Quebec seem to have declined substantially (if not in a statistically significant way) over the campaign, while they were generally unmoved in the ROC (details available from the author). Still, none of this upsets the conclusions of the present paper.

${ }^{13}$ For the NAES 2000 and NZES 2002, the items query respondent attitudes toward the economy "today" and "these days," respectively. Both items have been found instructive in previous analyses of these elections (Johnston, Hagen and Jamieson 2004; Vowles et al. 2004). For the OES 2003, the item asks respondents for a prospective evaluation about the likely economic performance of the incumbent and other
} 
variations across elections are such that comparisons of coefficients and effects across elections should proceed with caution. This fact does not trouble the present analysis, however, as the focus is on dynamics rather than relative magnitudes. Note that all the items are from the campaign wave of each election study, as use of post-election responses risks endogeneity bias (Lebo and Carey 2003). Each variable is scaled to run from 0 to 1 , where 1 indicates the most favourable economic evaluation. ${ }^{14}$

The treatment of the dependent variable also merits comment. Collapsing vote choice into a dichotomy between support for the incumbent and support for non-incumbents is obviously a simplification. Economic effects are not generally confined to incumbentsand indeed, economic effects on support for non-incumbents are present in the sample of elections examined here (see, for example, Clarke et al. 2004; Johnston, Hagen and Jamieson 2004; Blais et al. 2002). Still, these effects are typically complimentary to the effects on incumbent support-that is, these relationships are typically negative. Thus, operationalizing vote choice as a dichotomy, where 1 indicates support for the incumbent and 0 indicates support for non-incumbent parties, is a useful simplifying assumption that does little violence to reality. The operationalization is also true to the pith-andsubstance of the economic voting model-reward and punishment of incumbent governments for their economic performances (Key 1968; Fiorina 1981). ${ }^{15}$

\section{Linear Models}

Methodological preliminaries aside, the analysis can begin in Table 1. Note first what the table includes. In the first substantive column of the table are estimated coefficients on ECONEVAL in a 'static model,' that is, in a model that includes no interaction between campaign time and economic evaluations. This parameter summarizes the economic

parties. Response to this item is strongly related to a more standard retrospective measure (analysis unreported) and has been found useful in earlier analysis of that election (Cutler et al. 2004).

${ }^{14}$ Precise question wordings available from the author upon request.

${ }^{15}$ Note that the dependent variable captures vote intention (measured in the pre-campaign, RCS component of each election study), as using reported vote would erase the time variation in political cognition that is at the heart of the present inquiry. 
effect for the whole campaign assuming effects are time-invariant, and serves as an interpretive baseline. The heart of the matter is in the third and fourth columns of the table. Here, coefficients on ECONEVAL and ECONEVAL*DAY appear. This 'dynamic model' summarizes the over-time dynamics of economic effects, assuming the dynamics are linear in form. The final three columns render these dynamics in terms of predicted marginal effects. Columns 5 and 6 present, for the first and last days of the campaign period, the effect of a unit shift in economic evaluations (from worst to best evaluations) on the probability of incumbent support for a respondent who is otherwise ambivalent between voting for the incumbent and some other party (or candidate in the US case). ${ }^{16}$ The final column presents the difference between these quantities, the 'marginal effect shift.' Note that this approach results in the maximum possible marginal effects and likely exaggerates over-time dynamics as they actually were in these elections. The virtue of this approach, however, is that it makes comparisons across elections more sensible than, for example, evaluating marginal effects with other variables set to mean values - in such an approach the baseline probability of incumbent support would vary across elections as a consequence of the shape of the logistic curve, not as a result of real variation in economic effects (see Long 1997 for details).

The first important point made by Table 1 is that economic effects on the vote were significant in all of these elections. The coefficients from the static model summarize the pattern. Effects were substantively large in most of these elections and strikingly so in four of them: in New Zealand 1996 and 1999, Ontario 2003, and United Kingdom 2001. These findings should comfort students of economic voting in general, and also upset accepted wisdom about some of these elections (especially Canada 1993 and 2000, although these are the smallest effects of the lot).

The real interest is in the over-time changes, of course, and these emerge in the pattern of effects in the dynamic models. The first observation also may be a surprising one: the modal finding is no trend in economic effects. According to these models, five of the ten

\footnotetext{
16 'Ambivalent' respondents in this set up are those who have a baseline probability of supporting the incumbent of .5, i.e. the linear predictor equals zero.
} 
elections saw effectively no movement in the impact of the economy on the vote over the course of the campaign: Canada 1993 to 2000, New Zealand 1996, and United States 2000. The predicted marginal effect shift was zero in three of the elections and within six points of zero in the other two. These findings are consistent with at least two kinds of campaign dynamics: no dynamics at all and dynamics that are perfectly offsetting over time. The models cannot speak to these alternatives; the answer lies in the graphical analysis to come.

Three elections witnessed campaign period increases of substantive and statistical significance: Canada 1988, New Zealand 1999, and Ontario 2003. The marginal effect shifts were huge in two of these campaigns: better than thirty points in Canada 1988 and close to fifty in New Zealand 1999. Gains were more compressed in Ontario 2003, owing to the fact that the marginal effect of ECONEVAL was very large even on the first day of the campaign: .43. From there, diminishing returns in the logit model imply that there was very little room for effects to grow. In any case, only these three elections would seem to square with the enlightenment view.

The final two elections_-New Zealand 2002 and UK 2001—are decidedly at odds with enlightenment expectations. Economic effects appear to have declined over the course of these campaigns, although the trends are not statistically significant at conventional levels. Still, the marginal effect shifts seem substantively important, especially in New Zealand 2002, where the campaign would seem to have cut effects in half by election day. Voters in these elections, then, may have been diverted from the economic fundamentals by the campaign.

Looking across the table, however, the overriding point is this: no one pattern would seem to characterize the campaign dynamics of economic voting. Sometimes the campaign helps, sometimes it hurts, and sometimes it does nothing at all, at least as regards the magnitude of economic effects. 


\section{Curvilinear Models}

Perhaps this conclusion is the result of forcing a strict linear trend upon the dynamics of economic effects. The curvilinear set up, which incorporates an interaction between ECONEVAL and a quadratic DAY term, is obviously more flexible. In particular, these models allow for the possibility that the trend changes as the campaign progresses. A significant positive coefficient on $E C O N E V A L^{*} D A Y^{2}$, for instance, implies that growth in the impact of economic evaluations on vote choice accelerates as time passes. This is a possibility contemplated by Gelman and King (1993), among others, who suggest that voters have little incentive to pay much attention to the campaign until the very endwhen election day draws near and the need to overcome uncertainty about the candidates is at its height. Thus, they anticipate that the positive trend in economic effects on the vote will become steeper in the last days of the campaign. Of course, the coefficient on ECONEVAL ${ }^{*} D A Y^{2}$ could also be negative, implying that the rate of growth decelerates as campaign time passes, although it is not clear why this might be so.

Both possibilities are realized in Table 2. This table is set up much like Table 1, except here only coefficients from a single model — the curvilinear one-appear for each election. Three of the coefficients on the quadratic interaction with time reach conventional levels of statistical significance here: Canada 1988, New Zealand 1999 and Ontario 2003. The striking fact about these coefficients is that the signs on two of them are negative — Canada 1988 and New Zealand 1999. The impact of economic effects actually slows its growth—in fact, shrinks — as these campaigns come to a close. The overall pattern is still one of growth in marginal effects-marginal effect shifts even grow relative to those predicted in the linear set up ${ }^{17}$ —but the endpoint downturn is a theoretical surprise. This point returns below. Note for now that, among other things, this finding moderates the view of these two campaigns as strictly enlightening affairs.

\footnotetext{
${ }^{17}$ The marginal effect shift for NZ 1999-.97-seems absurd on its face. The result reflects the strongly negative estimated effect for ECONEVAL in the first days of the campaign. This estimated effect, in turn, implies a very steep positive trend in the impact of economic effects in the early part of the campaign.
} 
The significant positive coefficient on ECONEVAL*DAY2 is for Ontario 2003. Even so, the marginal effect shift actually shrinks a little in this model, a reflection of the negative trend in economic effects implied by the coefficient on ECONEVAL*DAY in the curvilinear model. Ontario 2003, then, also ceases to appear as a simplistically enlightening campaign. The model implies that voters were diverted from the economy for much of the campaign before refocusing on the consideration about halfway to election day. Is this enlightenment in its truest form, or something else?

Four other elections exhibit substantively interesting, if statistically insignificant, late campaign dynamics in economic effects. Two of these see endpoint increases in economic effects, the elections in the US and Canada in 2000, although marginal effect shifts still add up to naught. Two other elections see endpoint downturns in economic effects: New Zealand 1996 and 2002. The marginal effect shift for the 1996 contest is still roughly zero (as it was in the linear set up); for 2002, the drop in economic effects increases a little (from .17 to .22). Overall, however, these results do little to disturb the interpretations of these elections emerging from Table 1—all but New Zealand 2002 saw essentially no movement in economic effects over their respective campaigns.

The remaining three elections show no evidence of interesting late campaign dynamics. The coefficients on the quadratic interactions for Canada 1993 and 1997 are effectively zero-so these campaigns remain in the 'no movement' column-as is the coefficient on this term for UK 2001, a campaign that still appears to be basically 'de-enlightening' (if a little less so in terms of marginal effect shift than in the linear model).

Overall, then, reflections on the interaction between economic evaluations and a quadratic time term reinforce the conclusions following from the linear models: the modal result is no campaign dynamics in economic voting. Furthermore, the statistically significant late campaign movement that is uncovered undermines the 'enlightening' campaigns that seemed to emerge from the linear models. 
One other feature of the curvilinear estimates bears noting: six of the ten elections have negative coefficients on the linear interaction between economic evaluations and campaign time. This implies that economic effects were dropping (or, more precisely, that growth in effects was slowing) as these campaigns began, in line with what we might term the 'campaign diversion' hypothesis. Some of this movement is incidental-the coefficients for Canada 1993 and US 2000 are particularly small—but the overall pattern deserves comment. None of this fits with standard assumptions.

\section{A Closer Look at the Dynamics}

Most of the foregoing spells trouble for general accounts of campaign dynamics, whether of the enlightenment or some other variety. Of the three theoretical possibilities canvassed in the opening section of the paper, the best fit is really a 'non-theory theory': election campaigns are (at least largely) unpredictable in advance of the campaign, so we should not expect any particular pattern in the dynamics of any particular campaign. Need we go this far? Before passing judgment, a more inductive approach to the dynamics is in order.

This section of the paper takes a closer look at the campaign dynamics of economic voting by examining day-to-day change in economic effects. The approach is simple. For each election, a vote model ${ }^{18}$ is fit for each day of the campaign period. These estimates incorporate observations for five days - the period from two days before to two days after the day concerned. ${ }^{19}$ The economic effects estimates resulting from this 'moving average estimation' are then plotted as a line, separately for each campaign, and appear as Figures 1A-J. If there are interpretable patterns in the dynamics of economic

\footnotetext{
${ }^{18}$ The vote model for each election is the same as that in the 'static models' presented in Table 1, with one difference: given collinearity among variables for certain periods in some elections, there is some variation in the composition of the vote models within elections. This seems to make little difference substantively, as the plots are little different if a common, reduced form of the model is used instead (details available from the author). This makes statistical sense, of course: if a variable is dropped because it is collinear with some other variable(s), whatever variance that dropped variable shares with economic evaluations will be absorbed elsewhere in the model.

${ }^{19}$ As a result, no estimates are performed for the first two and last two days of the campaign period.
} 
effects, this approach will surely find them. Note that the scale of these plots is not constant: it changes a little from election to election, depending on the range of economic effects observed and the length of the campaign. The 'outliers' in this respect are the US and Canada 2000, where economic effects were quite modest throughout the campaign period. $^{20}$ This means little for interpretation of dynamics within elections (although sampling error is more pronounced in the plots covering a narrow range), but it rules out simplistic comparisons across campaigns.

First, an observation that is not possible in the context of linear or curvilinear assumptions about the dynamics: massive swings in the impact of the economy on vote choice are not unusual. Large shifts in the magnitude of economic effects are evident in every election except the US and Canada 2000 (where the economy did not amount to much anyway). Furthermore, the swings are not confined to the early campaign period, as the enlightenment view would lead us to expect (on this point, see Wlezien and Erikson 2002). Serious endpoint dynamics in economic effects are present in the plots for New Zealand 1996, Canada 1997 and, to a lesser extent, UK 2001. This would seem to suggest that, as a whole, the electorate is no more settled on the important elements of the vote at the end of the campaign than at the beginning. This is a bracing finding.

How do conclusions drawn from Tables 1 and 2 hold up in view of these plots? Portrayals of Canada 1988, New Zealand 1999 and Ontario 2003 as ultimately enlightening campaigns seem sound. Also in accordance with the picture painted by the models, the elections of Canada and the US in 2000 truly seem to have been devoid of real dynamics in economic effects. Dynamics in the remaining five elections, however, seem to have been seriously misconstrued in the earlier analysis. New Zealand 2002 and UK 2001, for instance, no longer appear to be simply 'diverting' campaigns. Both elections witnessed large gains in economic effects in the closing weeks of their campaigns, but these gains were almost totally erased on the eve of election day. Similar stories make sense for Canada 1993 and 1997 and New Zealand 1996. The impact of these campaigns seemed relatively neutral in the earlier analysis. Now all three show

\footnotetext{
${ }^{20}$ The US campaign is also about twice as long as the others.
} 
meteoric rises and catastrophic collapses in economic effects in roughly the last ten days of their campaigns.

The endpoint pattern of rise and fall bears emphasis. In fact, fully eight of the ten elections can plausibly be said to exhibit this pattern, if we add the three 'enlightening' campaigns to the list. It is not at all obvious what this means; an interpretive effort is made in the conclusion. What is obvious is that the pattern is not enlightenment or diversion, and that it is too much of a pattern to be compatible with the 'unpredictable' view of campaigns. Something seems to be happening in all these campaigns, but what is it?

Overall, then, the graphical analysis ends up in a place that is partially of a piece with, partially at odds with the conclusions of the more formal statistical analysis. The theories on offer do not capture the findings. At the same time, the modal result does not seem to be 'no campaign dynamics in economic voting.' Indeed, the plots at times bespeak massive swings in the impact of the economy on the vote. And there is something new to explain: endpoint spikes in economic effects.

\section{Discussion and Conclusion}

The dominant pattern in the campaign dynamics of economic voting does not square with either of the obvious theoretical stories. Most strikingly, the campaigns examined here do not appear to have been enlightening, at least not in any simplistic, monotonic way, as implied by the literature. At the same time, the campaigns were not simply diverting affairs. In short, no straightforward linear trend-either positive or negativesummarizes the dynamics very well.

The failure of the enlightenment view is the bigger surprise. There is evidence of enlightenment in election campaigns (see fn. 1 above). Most of the work speaks only indirectly to the campaign dynamics of economic voting, but the direct evidence on the 
question is compelling (Bartels Forthcoming). We also have the predictive record of dozens of election forecasting models for which we must account. How can economic variables be so predictive in the aggregate if there is no particular tendency for campaigns to enliven the economy-vote link?

Perhaps this begs the question. It might be that there is some chronic level of voter attentiveness to economic considerations that is sufficient for the forecasting models to work, at least most of the time. Still, it would be strange if such a chronic level of attentiveness were so plastic in the campaign season.

Upsetting the enlightenment view raises another interesting question: when does enlightenment happen? One key variable seems to be campaign balance. The argument is this: whatever the incentives of campaigners to draw voter attention to fundamental considerations - like the economy - they may not always have the resources with which to do so. A weak opposition may never be able to enforce accountability on incumbents, for instance. Enlightenment dynamics in the domain of the economy may also be elastic to some of the variables that have been found important in the cross-national literature on economic voting - clarity of responsibility, the presence of viable alternatives, and the like (Powell and Whitten 1993; Anderson 1995). To the extent that these features of context vary across the set of elections examined here, these variables may go some distance in explaining the overall pattern. This is a compelling research agenda.

Enlightenment aside, the pattern of massive swings in economic effects over the campaign has implications for the interpretation of campaign period polls. It is common to assume that survey responses early in the campaign are more fluid, less sticky than those closer to election day (consider Wlezien and Erikson 2002). If this is the case, it does not appear to be because voters settle on the nature of the 'ballot question' as the election draws near. The ingredients of the vote decision appear to be about as malleable at the end of the campaign as at the beginning, if the pattern for economic evaluations is any indication. This certainly has implications for the interpretation of polling results, and possibly also for campaign strategy. 
What of the 'endpoint spike' in economic effects? A novel interpretation is this: ambivalent, uninformed voters are more likely to form vote intentions and appear in survey samples at the end of campaigns — at the very end of campaigns - than at the beginning. If truly uninformed and ambivalent, economic effects in this group should be much weaker than in the population more generally. As a result, their entry into the population of survey respondents obscures the more general pattern of growing attentiveness to the economy (enlightenment) characteristic of the rest of the sample. The endpoint spike in economic effects is, thus, an artefact of a selection process. ${ }^{21}$

The 'artefact hypothesis' is a fascinating suggestion to which the present analysis cannot speak very clearly, but there is reason for doubt. In order for this process to account for the catastrophic collapses in economic effects observed across so many of these elections, two premises would have to be true: these ambivalent, uninformed respondents make up a hugely disproportionate share of survey respondents at the end of election campaigns; and the nature of economic effects on vote choice for such respondents is seriously at odds with—often the inverse of—-such effects for other respondents. Neither premise seems very plausible.

What, then, explains the endpoint spike? All is speculation. One possibility is that the hurly burly of the final week of campaigning - with its typical focus on candidates and personalities_ - undoes much of the 'good work' of the early campaign. Another possibility is that the final week of the campaign fixes voter attention on fundamentals other than the economy: campaign organization on the ground is all about mobilizing the base-perhaps the process primes partisanship and social group memberships, forcing economic and related 'nature of the times' (Campbell et al. 1960) considerations from centre stage. Of course, the spike implies that these elements of the vote are themselves waiting in the wings in the weeks prior to the final week of mobilization. The claim seems implausible on its face and is also at odds-once again — with the accumulated evidence in favour of campaign enlightenment.

\footnotetext{
${ }^{21}$ This interpretation owes much to a suggestion from Fred Cutler.
} 
The paper, thus, concludes with unanswered questions. Here, it is worth remarking on the decontextualized approach of the foregoing analysis. The historical details of these ten elections and their campaigns have been stripped away. The reason is this: the question at the root of the analysis was, is there a pattern in the campaign dynamics of economic voting? If there is, a general account of campaigns — such as enlightenment or diversion-would seem to suffice. If not, then this counsels a focus on the details and the history - what is contingent about and peculiar to each campaign. In this way, we may hope to 'bring the campaign back in' to the study of campaign effects. 


\section{Bibliography}

Andersen, Robert, James Tilley and Anthony Heath. 2005. 'Political Knowledge and Enlightened Preferences: Party Choice Through the Electoral Cycle.' British Journal of Political Science 35: 285-302.

Anderson, Christopher. 1995. Blaming the Government: Citizens and the Economy in Five European Democracies. Armonk, N.Y.: M.E. Sharpe.

Arceneaux, Kevin. 2004. 'Do Campaigns Help Voters Learn?: A Cross-national Analysis.’ Yale University: Institute for Policy and Social Studies (unpublished manuscript).

Bafumi, Joseph, Andrew Gelman and David Park. 2004. 'What Does “Do Campaigns Matter?” Mean?’ Columbia University (unpublished manuscript).

Bartels, Larry. 1992. 'The Impact of Electioneering in the United States,' in Electioneering: A Comparative Study of Continuity and Change, eds. David Butler and Austin Ranney. Oxford: Clarendon Press.

Bartels, Larry. Forthcoming. 'Priming and Persuasion in Presidential Campaigns,' in Capturing Campaign Effects, eds. Henry Brady and Richard Johnston. Ann Arbor: University of Michigan Press.

Blais, André, Richard Nadeau, Elisabeth Gidengil, and Neil Nevitte. 2002. Anatomy of a Liberal Victory: Making Sense of the Vote in The 2000 Canadian Election. Peterborough: Broadview Press.

Campbell, Angus, Philip Converse, Warren E. Miller and Donald E. Stokes. 1960. The American Voter. New York: Wiley \& Sons.

Campbell, James. 2000. The American Campaign: U.S. Presidential Campaigns and the National Vote. College Station, TX: Texas A \& M Press.

Campbell, James. 2001. 'The Referendum That Didn't Happen: The Forecasts of the 2000 Presidential Election.’ PS: Political Science and Politics 34: 33-4.

Clarke, Harold, David Sanders, Marianne C. Stewart and Paul Whiteley. 2004. Political Choice in Britain. Oxford: Oxford University Press.

Cutler, Fred, Patrick Fournier, Stuart Soroka and Greg Lyle. 2004. 'The 2003 Ontario Election: Campaigns, Advertising, Debates, Bandwagons, and Issue Importance.' Paper presented at the Annual Meeting of the Canadian Political Science Association, Winnipeg, MB. 
Downs, Anthony. 1957. An Economic Theory of Democracy. New York: Harper Collins.

Finkel, Steven. 1993. 'Reexamining the Minimal Effects Model in Recent Presidential Campaigns.' Journal of Politics 55: 1-21.

Fiorina, Morris P. 1981. Retrospective Voting in American National Elections. New Haven: Yale University Press.

Gelman, Andrew and Gary King. 1993. 'Why Are American Presidential Election Campaign Polls So Variable When Votes Are So Predictable?' British Journal of Political Science 23: 409-451.

Holbrook, Thomas. 1996. Do Campaigns Matter? Thousand Oaks, California: Sage Publications.

Holbrook, Thomas. 2001. 'Forecasting with Mixed Economic Signals: A Cautionary Tale.’ PS: Political Science and Politics 34: 39-44.

Johnston, Richard, André Blais, Henry Brady, and Jean Crête. 1992. Letting the People Decide: Dynamics of a Canadian Election. Montreal: McGill-Queen's University Press.

Johnston, Richard and Henry Brady. 2002. 'The Rolling Cross-Section Design.' Electoral Studies 21: 283-95.

Johnston, Richard, Michael Hagen and Kathleen Hall Jamieson. 2004. The 2000 Presidential Election and the Foundations of Party Politics. Cambridge: Cambridge University Press.

Key, V. O. 1968. The Responsible Electorate: Rationality in Presidential Voting, 19361960. New York, NY: Vintage Books.

Lebo, Matthew and Sean Carey. 2003. 'Election cycles and the retrospective voter.' Paper presented at the Annual Meeting of the American Political Science Association, Philadelphia, August 28-31, 2003.

Long, J. Scott. 1997. Regression Models for Categorical and Limited Dependent Variables. Thousand Oaks, CA: Sage Publications Ltd.

Lupia, Arthur and Matthew McCubbins. 1998. The Democratic Dilemma: Can Citizens Learn What They Need to Know? New York: Cambridge University Press.

Markus, Gregory. 1988. 'The Impact of Personal and National Economic Conditions on the Presidential Vote: A Pooled Cross-sectional Analysis.' American Journal of Political Science 32: 137-154. 
Markus, Gregory. 1992. 'The impact of personal and national economic conditions on presidential voting, 1956-1988.’ American Journal of Political Science 36-3: 829.

Nadeau, Richard, Richard G. Niemi, and Antoine Yoshinaka. 2002. ‘A cross-national analysis of economic voting: taking account of the political context across time and nations.' Electoral Studies 21-3: 403.

Norpoth, Helmut. 2001. 'Primary Colors: A Mixed Blessing for Al Gore.' PS: Political Science and Politics 34: 45-8.

Palmer, Harvey D. and Guy D. Whitten. 2003. 'Questionable Analyses with No Theoretical Innovation: A Response to Royed, Leyden and Borrelli.' British Journal of Political Science 33-1: 139.

Popkin, Samuel. 1991. The Reasoning Voter. Chicago: University of Chicago Press.

Powell, G. Bingham and Guy Whitten. 1993. 'A Cross-national Analysis of Economic Voting: Taking Account of the Political Context.' American Journal of Political Science 37-2: 391-414.

Royed, Terry, Kevin Leyden and Stephen Borelli. 2000. 'Is 'Clarity of Responsibility' Important for Economic Voting? Revisiting Powell and Whitten's Hypothesis.' British Journal of Political Science 30:669-698.

Sekhon, Jasjeet. 2004. 'The Varying Role of Voter Information Across Democratic Societies.' Harvard University (unpublished manuscript).

Shaw, Daron R. 1999. 'A Study of Presidential Campaign Event Effects from 1952 to 1992.' Journal of Politics 61-2: 387-423.

Stevenson, Randolph and Lynn Vavreck. 2000. 'Does Campaign Length Matter? Testing for Cross-national Effects.’ British Journal of Political Science 30: 217-35.

Vowles, Jack, Peter Aimer, Susan Banducci, Jeffrey Karp and Raymond Miller. 2004. Voters' Veto: The 2002 Election in New Zealand and the Consolidation of Minority Government. Auckland: Auckland University Press.

Wlezien, C. and R. S. Erikson. 2002. 'The Timeline of Presidential Election Campaigns.' Journal of Politics 64-4: 969-94. 
Table 1. The Dynamics of Economic Effects - Linear Models (Logit Estimates)

\begin{tabular}{|c|c|c|c|c|c|c|}
\hline & \multicolumn{6}{|c|}{ Dynamic Model } \\
\hline & ECONEVAL & ECONEVAL & $\begin{array}{c}\text { ECONEVAL } \\
* D A Y \\
\end{array}$ & $\begin{array}{c}\text { First Day } \\
\text { Effect }\end{array}$ & $\begin{array}{l}\text { Last Day } \\
\text { Effect }\end{array}$ & $\begin{array}{c}\text { Marginal } \\
\text { Effect Shift }\end{array}$ \\
\hline \multirow{2}{*}{$\begin{array}{l}\text { CDA } \\
1988\end{array}$} & $1.1507 * * *$ & 0.2507 & $0.0369 *$ & 0.06 & 0.38 & 0.32 \\
\hline & $(0.2517)$ & $(0.5457)$ & (0.0199) & & & \\
\hline \multirow{2}{*}{$\begin{array}{l}\text { CDA } \\
1993\end{array}$} & $0.4079 *$ & 0.2897 & 0.0052 & 0.07 & 0.13 & 0.06 \\
\hline & $(0.2100)$ & $(0.4159)$ & (0.0159) & & & \\
\hline \multirow{2}{*}{$\begin{array}{l}\text { CDA } \\
1997\end{array}$} & $0.9576 * * *$ & $0.8761 * * *$ & 0.0043 & 0.21 & 0.24 & 0.03 \\
\hline & $(0.2097)$ & $(0.3317)$ & $(0.0166)$ & & & \\
\hline \multirow{2}{*}{$\begin{array}{l}\text { CDA } \\
2000\end{array}$} & $0.5998 * * *$ & $0.5922 *$ & 0.0004 & 0.14 & 0.15 & 0.00 \\
\hline & $(0.1603)$ & $(0.3255)$ & $(0.0140)$ & & & \\
\hline \multirow{2}{*}{$\begin{array}{l}\mathrm{NZ} \\
1996\end{array}$} & $2.6644 * * *$ & $2.6541^{* * *}$ & 0.0006 & 0.43 & 0.44 & 0.00 \\
\hline & $(0.3263)$ & $(0.4648)$ & $(0.0270)$ & & & \\
\hline \multirow[t]{2}{*}{$\begin{array}{l}\text { NZ } \\
1999\end{array}$} & $2.5285^{* * *}$ & -0.0905 & $0.1021^{* *}$ & -0.02 & 0.45 & 0.47 \\
\hline & $(0.4024)$ & (1.3136) & $(0.0467)$ & & & \\
\hline \multirow{2}{*}{$\begin{array}{l}\text { NZ } \\
2002\end{array}$} & $1.1871^{*}$ & $1.6662 *$ & -0.0263 & 0.34 & 0.17 & -0.17 \\
\hline & $(0.6122)$ & $(0.9400)$ & $(0.0685)$ & & & \\
\hline \multirow[t]{2}{*}{$\begin{array}{l}\text { ONT } \\
2003\end{array}$} & $3.3350 * * *$ & $2.6192 * * *$ & $0.0520 *$ & 0.43 & 0.48 & 0.05 \\
\hline & $(0.2835)$ & $(0.4558)$ & $(0.0310)$ & & & \\
\hline \multirow{2}{*}{$\begin{array}{l}\text { UK } \\
2001\end{array}$} & $2.0624 * * *$ & $2.5261 * * *$ & -0.0322 & 0.43 & 0.33 & -0.10 \\
\hline & $(0.2005)$ & $(0.4262)$ & $(0.0239)$ & & & \\
\hline \multirow[t]{2}{*}{$\begin{array}{l}\text { US } \\
2000\end{array}$} & $0.7878^{* * *}$ & $0.7951 * * *$ & -0.0002 & 0.19 & 0.19 & 0.00 \\
\hline & $(0.0621)$ & $(0.1143)$ & $(0.0030)$ & & & \\
\hline
\end{tabular}

Robust standard errors in parentheses; * significant at 10\%; ** significant at 5\%; *** significant at $1 \%$ 
Table 2. The Dynamics of Economic Effects - Curvilinear Models (Logit Estimates)

\begin{tabular}{|c|c|c|c|c|c|c|}
\hline & ECONEVAL & $\begin{array}{c}\text { ECONEVAL } \\
* D A Y\end{array}$ & $\begin{array}{c}\text { ECONEVAL } \\
* D A Y^{2}\end{array}$ & $\begin{array}{c}\text { First Day } \\
\text { Effect }\end{array}$ & $\begin{array}{c}\text { Last Day } \\
\text { Effect }\end{array}$ & $\begin{array}{c}\text { Marginal } \\
\text { Effect Shift }\end{array}$ \\
\hline \multirow[t]{2}{*}{$\begin{array}{l}\text { CDA } \\
1988\end{array}$} & -0.6428 & $0.1430^{* *}$ & $-0.0022 *$ & -0.16 & 0.27 & 0.43 \\
\hline & $(0.7390)$ & $(0.0654)$ & $(0.0013)$ & & & \\
\hline \multirow{2}{*}{$\begin{array}{l}\text { CDA } \\
1993\end{array}$} & 0.3504 & -0.0021 & 0.0002 & 0.09 & 0.16 & 0.07 \\
\hline & $(0.6368)$ & $(0.0672)$ & $(0.0014)$ & & & \\
\hline \multirow[t]{2}{*}{$\begin{array}{l}\text { CDA } \\
1997\end{array}$} & $1.0514^{* *}$ & -0.0199 & 0.0006 & 0.24 & 0.25 & 0.01 \\
\hline & $(0.5274)$ & $(0.0736)$ & (0.0019) & & & \\
\hline \multirow{2}{*}{$\begin{array}{l}\text { CDA } \\
2000\end{array}$} & $0.9224^{*}$ & -0.0457 & 0.0012 & 0.22 & 0.18 & -0.04 \\
\hline & $(0.5510)$ & $(0.0631)$ & $(0.0016)$ & & & \\
\hline \multirow{2}{*}{$\begin{array}{l}\text { NZ } \\
1996\end{array}$} & $2.1380 * * *$ & 0.0720 & -0.0018 & 0.39 & 0.41 & 0.02 \\
\hline & $(0.6276)$ & $(0.0977)$ & $(0.0026)$ & & & \\
\hline \multirow{2}{*}{$\begin{array}{l}\text { NZ } \\
1999\end{array}$} & $-5.5029 *$ & $0.5950 * * *$ & $-0.0098 * *$ & -0.50 & 0.47 & 0.97 \\
\hline & (3.0608) & $(0.2264)$ & $(0.0040)$ & & & \\
\hline \multirow[t]{2}{*}{$\begin{array}{l}\text { NZ } \\
2002\end{array}$} & 0.8127 & 0.1222 & -0.0041 & 0.19 & -0.03 & -0.22 \\
\hline & (1.0038) & $(0.1905)$ & $(0.0063)$ & & & \\
\hline \multirow[t]{2}{*}{$\begin{array}{l}\text { ONT } \\
2003\end{array}$} & $3.7244 * * *$ & -0.1568 & $0.0072 *$ & 0.48 & 0.49 & 0.02 \\
\hline & $(0.8494)$ & $(0.1261)$ & $(0.0039)$ & & & \\
\hline \multirow{2}{*}{$\begin{array}{l}\text { UK } \\
2001\end{array}$} & $2.6176^{* * *}$ & -0.0528 & 0.0007 & 0.43 & 0.34 & -0.09 \\
\hline & $(0.6842)$ & $(0.1087)$ & $(0.0036)$ & & & \\
\hline \multirow[t]{2}{*}{$\begin{array}{l}\text { US } \\
2000\end{array}$} & $0.8326 * * *$ & -0.0039 & 0.0001 & 0.20 & 0.23 & 0.03 \\
\hline & $(0.1542)$ & (0.0119) & $(0.0002)$ & & & \\
\hline
\end{tabular}

Robust standard errors in parentheses; * significant at 10\%; ${ }^{* *}$ significant at 5\%; ${ }^{* * *}$ significant at $1 \%$ 

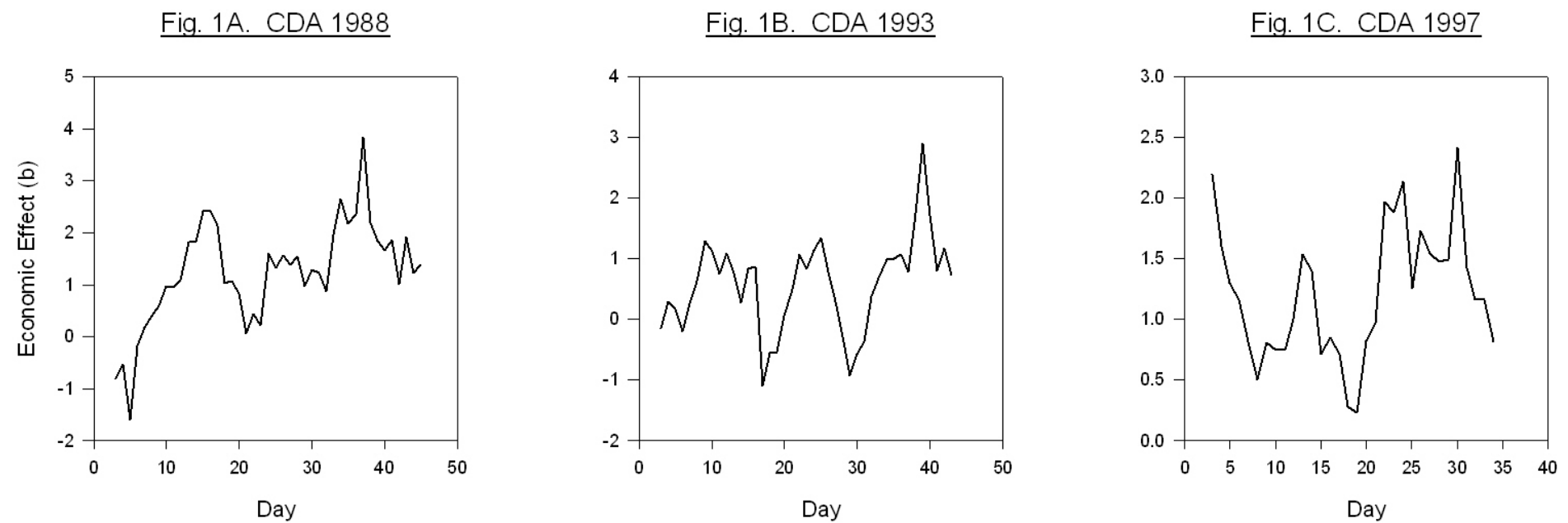

Fig. 1D. CDA 2000

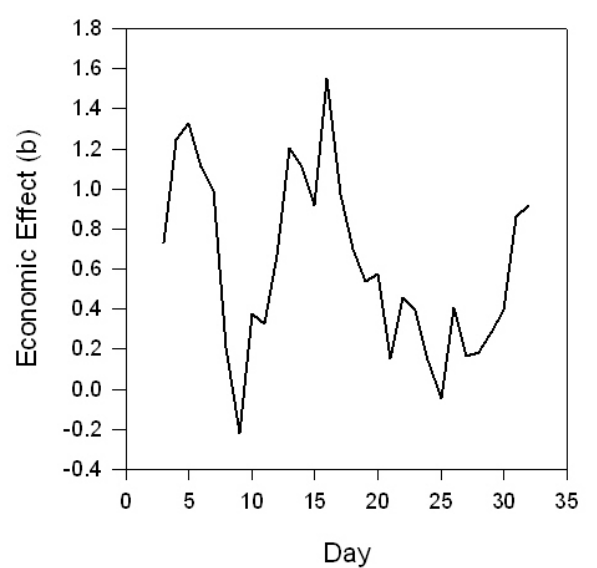

Fig. 1E. NZ 1996

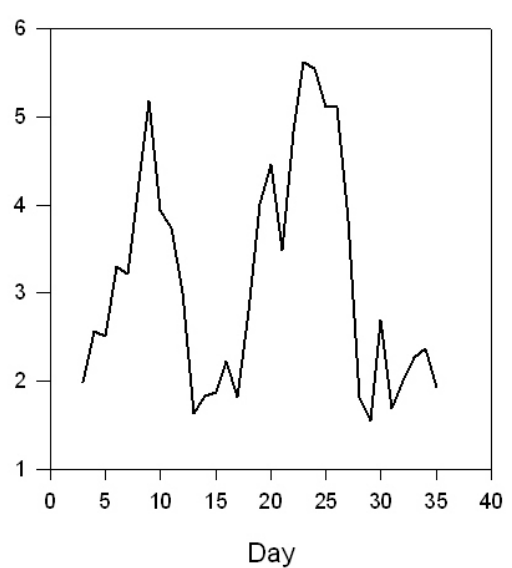

Fig. 1F. NZ 1999

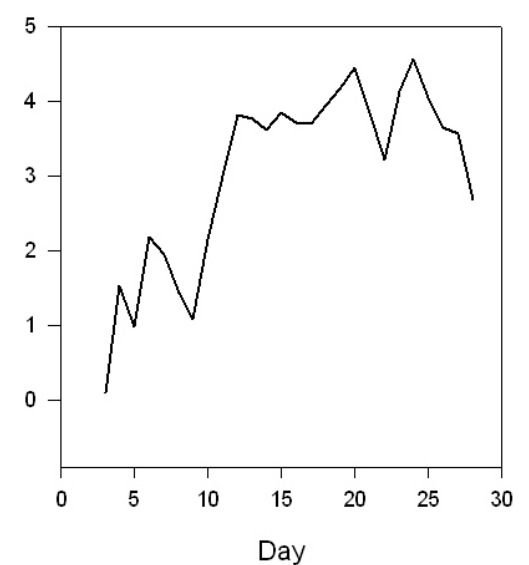



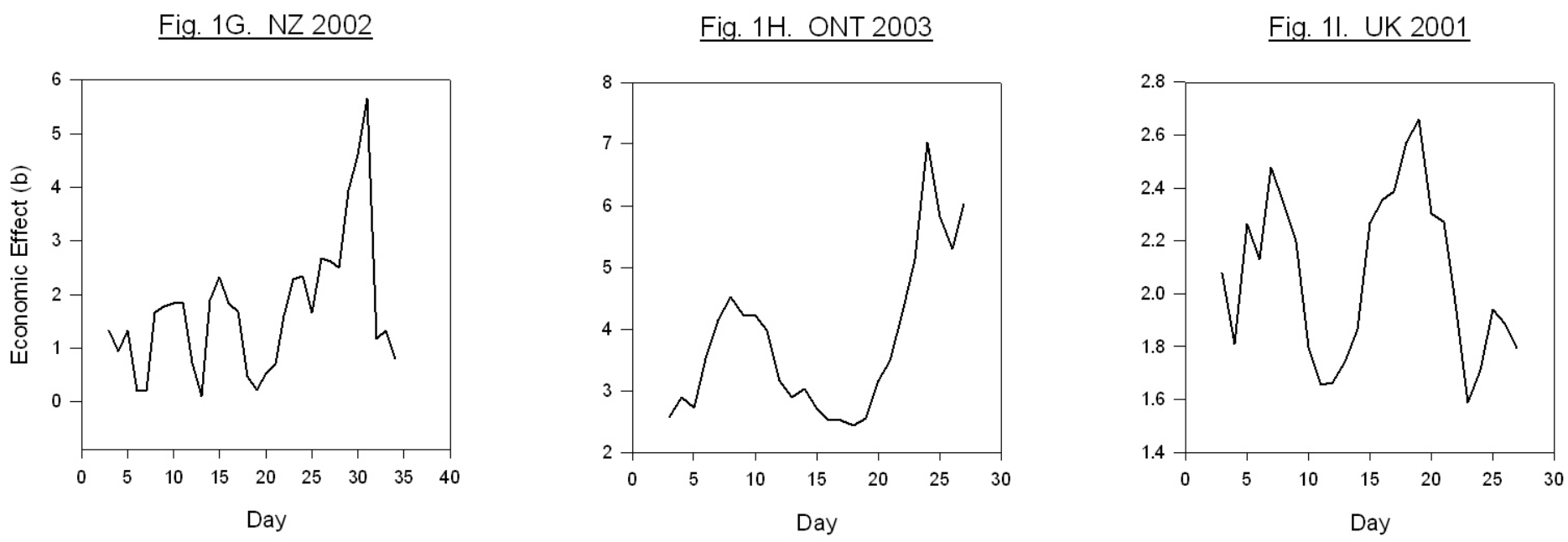

Fig. 1J. US 2000

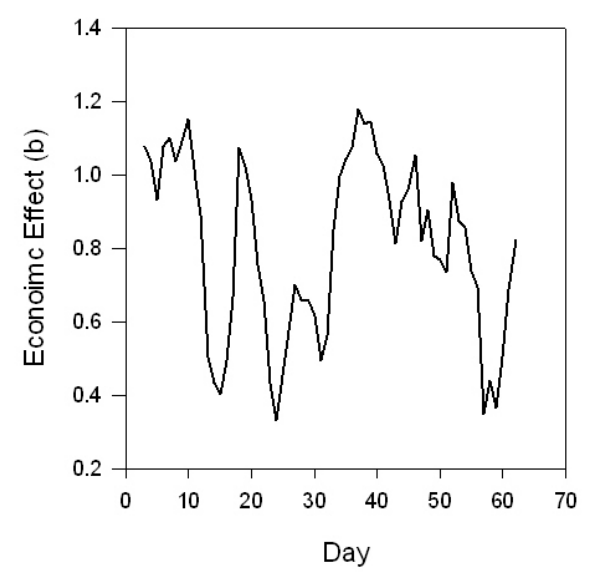

